\title{
Sistem Pemantauan Gas Karbon Monoksida (CO) pada Produk KOLISS-IoT Menggunakan Teknologi Web
}

\author{
Krisna Aditya ${ }^{1}$, Dian Budhi Santoso ${ }^{2}$, Lela Nurpulaela ${ }^{3}$ \\ 1,2,3Program Studi Teknik Elektro, \\ Fakultas Teknik, \\ Universitas Singaperbangsa Karawang, Karawang \\ ${ }^{1}$ krisna.aditya16073@student.unsika.ac.id, ${ }^{2}$ dian.budhi@ft.unsika.ac.id, \\ 3lela.nurpulaela@ft.unsika.ac.id
}

\begin{abstract}
Abstrak
Penelitian ini bertujuan untuk mengetahui kandungan gas karbon monoksida (CO) pada produk kompor penghasil listrik dengan teknologi Internet of Things (KOLISS-IoT) yang berpotensi menghasilkan gas $\mathrm{CO}$ dari pembakaran yang tidak sempurna. Metode yang digunakan dalam pembuatan alat ini diawali dengan pembuatan produk KOLISS-IoT dan pembuatan sistem pemantauan gas $\mathrm{CO}$ yang didukung dengan teknologi Internet of Things (IoT). Proses pemantauan gas CO menggunakan sensor gas tipe MQ-7, sebagai pengendalinya menggunakan Arduino Uno serta untuk menampilkan hasil pemantauan pada halaman web menggunakan modul WiFi ESP8266 sebagai pengirim datanya. Berdasarkan hasil pengujian yang telah dilakukan, sensor MQ-7 dapat mendeteksi gas karbon monoksida (CO) pada produk KOLISS-IoT yang selanjutnya ditampilkan di LCD dan halaman web. Hasil pengambilan data didapatkan rata-rata gas $\mathrm{CO}$ yang terdeteksi sebesar 5,72 ppm serta rata-rata waktu pengiriman data pada halaman web membutuhkan waktu 8,1 detik.
\end{abstract}

Kata kunci: pemantauan, sensor MQ-7, karbon monoksida (CO), Internet of Things (IoT)

\begin{abstract}
This study aims to find out the concentration of carbon monoxide (CO) gas in electric stoves by means of Internet of Things technology (KOLISS-IoT) that potentially produces CO gas from incomplete combustion. The method used in making electric stove begins with making the product of KOLISS-IoT and CO gas monitoring systems supported by the internet of things (IoT) technology. The CO gas monitoring process uses the MQ-7 type gas sensor, Arduino Uno as the controller, and ESP8266 WiFi module as the sender of the data to display the result of monitoring on the webpage. Based on the tests that have been conducted, MQ-7 sensors can detect carbon monoxide (CO) gases in KOLISS-IoT products that are subsequently displayed on LCD and webpages. The results of this study implies that the average of CO gas was 5.72 ppm of and the average of data delivery time on web pages was 8.1 seconds.
\end{abstract}

Keywords: monitoring, MQ-7 sensors, carbon monoxide (CO), Internet of Things (IoT)

\section{Pendahuluan}

Produk KOLISS-IoT merupakan kompor penghasil listrik dengan teknologi Internet of Things (IoT) yang memanfaatkan sumber energi panas dari proses pembakaran bahan 
bakar biomassa untuk dapat menghasilkan listrik, dengan menggunakan thermoelectric generator (TEG) yang mengubah perbedaan suhu di antara dua sisi elemen yang akan mengalirkan arus sehingga menghasilkan perbedaan tegangan [1]. Semakin besar beda suhu antara kedua sisi pada modul TEG, maka semakin besar pula tegangan yang dihasilkan oleh elemen tersebut.

KOLISS-IoT merupakan produk yang dalam pembakarannya memakai bahan biomassa padat seperti kayu, tumbuh-tumbuhan, daun-daunan, rumput, limbah pertanian, dan sebagainya. Bahan biomassa padat terutama kayu sampai saat ini masih dimanfaatkan di daerah pelosok pedesaan untuk memasak, biasanya dipakai pada dapur tradisional atau pembakaran secara langsung.

Pembakaran terbuka dengan bahan bakar biomassa menghasilkan beberapa emisi polutan yaitu karbon monoksida (CO), hidrogen sulfida (H2S), nitrogen oksida (NOx), sulfur dioksida (SOx) serta partikel debu [2]. Pembakaran yang menghasilkan emisi polutan dapat mengotori ruangan dan dapat mempercepat terjadinya pemanasan global [3]. Riset kesehatan menunjukkan bahwa adanya hubungan antara polusi asap yang dihasilkan dari pembakaran tungku dengan banyak macam penyakit seperti infeksi saluran pernafasan [4], bronkitis kronis [5], asma [6], hingga TBC. Kejadian ini terutama terjadi di Indonesia dan negara lain yang masih dalam status negara berkembang [7].

Salah satu gas yang yang paling berbahaya dari pembakaran terbuka adalah karbon monoksida (CO), yang dihasilkan oleh proses pembakaran tak sempurna [8]. Karakter CO yang tidak berwarna, tidak berbau, tidak berasa, mudah terbakar, dan tidak mengiritasi membuat gas ini kehadirannya sering tidak disadari oleh manusia [9]. Memiliki efek yang beracun dan mematikan, $\mathrm{CO}$ juga dikenal sebagai pembunuh diam-diam. Tingkat konsentrasi $\mathrm{CO}$ di suatu area yang cukup tinggi akan membahayakan manusia tetapi tergantung dari lamanya manusia terpapar gas CO. Paparan gas $\mathrm{CO}$ yang dianjurkan oleh Occupational Safety and Health Administration (OSHA) yang merupakan bagian dari Departemen Tenaga Kerja Amerika Serikat adalah apabila beraktifitas di ruangan selama 8 jam tingkat konsentrasi maksimal gas CO-nya adalah 35 ppm [10].

Pemantauan terhadap kandungan gas CO pada produk KOLISS-IoT yang berpotensi menghasilkan gas $\mathrm{CO}$ menjadi hal yang sangat penting mengingat udara yang bersih merupakan hal yang sangat vital bagi manusia. Banyak cara yang dapat digunakan untuk mengukur kandungan gas CO pada produk KOLISS-IoT salah satunya dengan menggunakan sensor yang dipasang pada cerobong asap yang berpotensi menghasilkan kandungan gas $\mathrm{CO}$.

Berkembangnya teknologi komunikasi saat ini memudahkan dalam proses pemantauan. Salah satu teknologi yang sedang berkembang yaitu Internet of Things (IoT) yang memanfaatkan akses dari internet sehingga sangat memudahkan dalam proses pemantauan gas CO. IoT memungkinkan pengguna untuk mengelola dan mengoptimalkan elektronik dan peralatan listrik yang menggunakan internet dan saling bertukar informasi satu sama lain di antara mereka sehingga mengurangi interaksi manusia [11]. Penelitian yang dilakukan [12] menjelaskan tentang sistem pemantauan gas CO pada cerobong asap industri yaitu dengan menempatkan sensor MQ-7 pada cerobong asap industri. Sistem ini menggunakan modul Bluetooth HC-06 untuk mengkoneksikan dari Arduino Uno ke media gadget Android sehingga data dari sensor dapat ditampilkan di aplikasi MIT APP Inventor.

Melihat permasalahan dan dari penelitian [12], tercetus ide untuk membuat sistem pemantauan gas CO pada produk KOLISS-IOT yang berpotensi menghasilkan gas CO dari 
hasil pembakaran yang tidak sempurna. Sensor yang dipakai untuk mendeteksi karbon monoksida yaitu sensor gas tipe MQ-7 yang sangat peka terhadap karbon monoksida. Sistem ini didukung dengan teknologi IoT yang dapat melihat hasil pemantauan pada halaman web. Dari sistem pemantau gas CO ini diharapkan dapat mengetahui gas CO yang dihasilkan dari pembakaran terbuka dan tidak sempurna dari produk KOLISS-IoT. Rancangan ini bekerja berdasarkan sistem elektronik yang dikendalikan berdasarkan perintah dari Arduino uno yang dilengkapi dengan sensor gas MQ-7, Liquid Crystal Display (LCD) dan modul WiFi ES8266.

\section{Metodologi Penelitian}

Dalam penelitian ini menggunakan metode rancang bangun yang terdiri dari beberapa tahap yaitu: identifikasi kebutuhan, analisis kebutuhan, perancangan sistem, perancangan perangkat keras dan lunak, pembuatan alat dan pengujian alat. Komponen sistem pemantauan gas CO ini terdiri dari perangkat keras yaitu Arduino Uno, sensor MQ-7, LCD I2C serta modul WiFi ESP8266 yang berperan sebagai server dan perangkat lunak yang diprogram menggunakan software Arduino IDE.

\subsection{Waktu dan Tempat}

Penelitian ini dimulai pada bulan Desember 2019 sampai Juni 2020, dengan menggunakan tempat kos penulis dan Laboratorium Teknik Elektro, Universitas Singaperbangsa Karawang.

\subsection{Perancangan Desain}

Desain alat ini dibuat untuk memudahkan dalam pembuatan dan pengujian alat. Desain alat tersebut dapat dilihat pada Gambar 1.

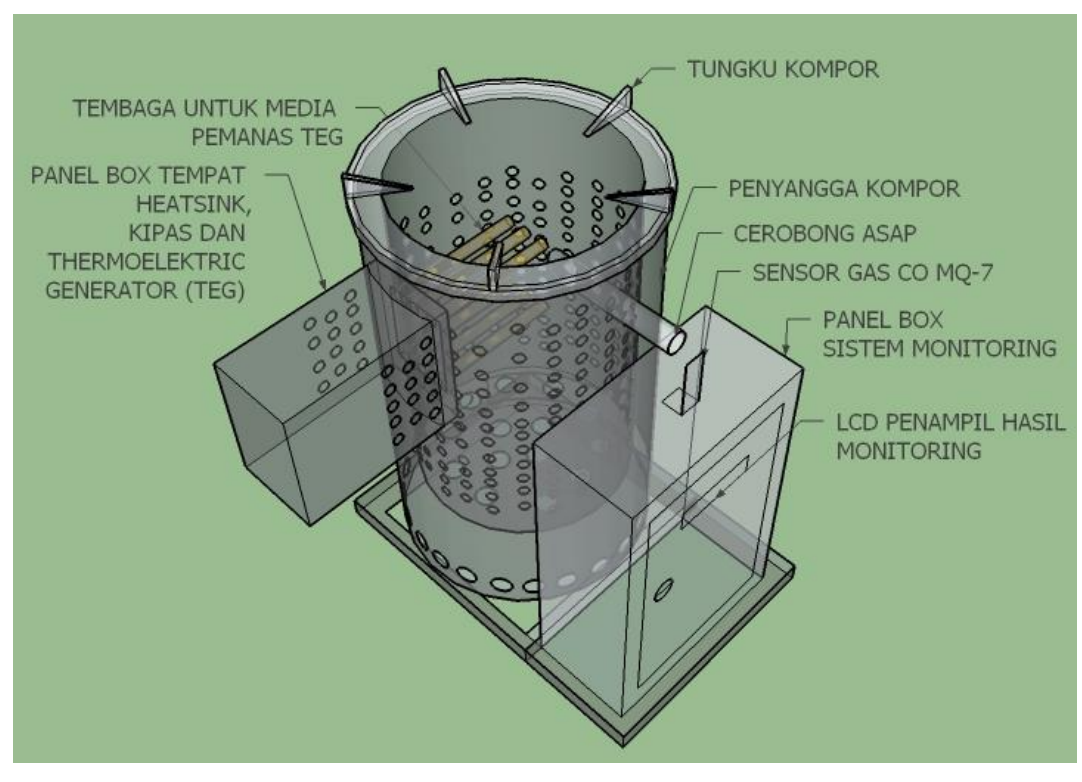

Gambar 1. Desain alat

Desain alat ini menggunakan pelat besi yang dibentuk menjadi kompor sebagai tempat pembakaran. Panel box diletakkan di samping kompor untuk menyimpan komponen 
seperti Arduino Uno, modul WiFi ESP8266 serta LCD. Bagian atas panel box dibuat cerobong asap dengan tujuan agar asap hasil pembakaran yang berpotensi menghasilkan gas CO dapat terdeteksi oleh sensor MQ-7 yang sudah diletakkan pada ujung cerobong asap.

\subsection{Skema Rangkaian Alat}

Rangkaian alat ini menggunakan Arduino Uno dengan Atmega328 sebagai mikrokontrolernya. Arduino Uno memiliki 14 port input dan output digital dan juga 6 port input dan output analog. Peracangan hardware dari rangkaian sensor gas MQ-7 ini hanya 3 pin saja yang dipakai yaitu pin VCC sensor yang dihubungkan dengan $+5 \mathrm{~V}$ dari pin Arduino, pin GND sensor dihubungkan dengan pin GND Arduino serta pin A0 sensor dihubungkan dengan pin A0 Arduino. Nilai analog yang didapat dari sensor MQ-7 selanjutnya diolah dan diubah ke dalam bentuk standar gas ppm (part per million).

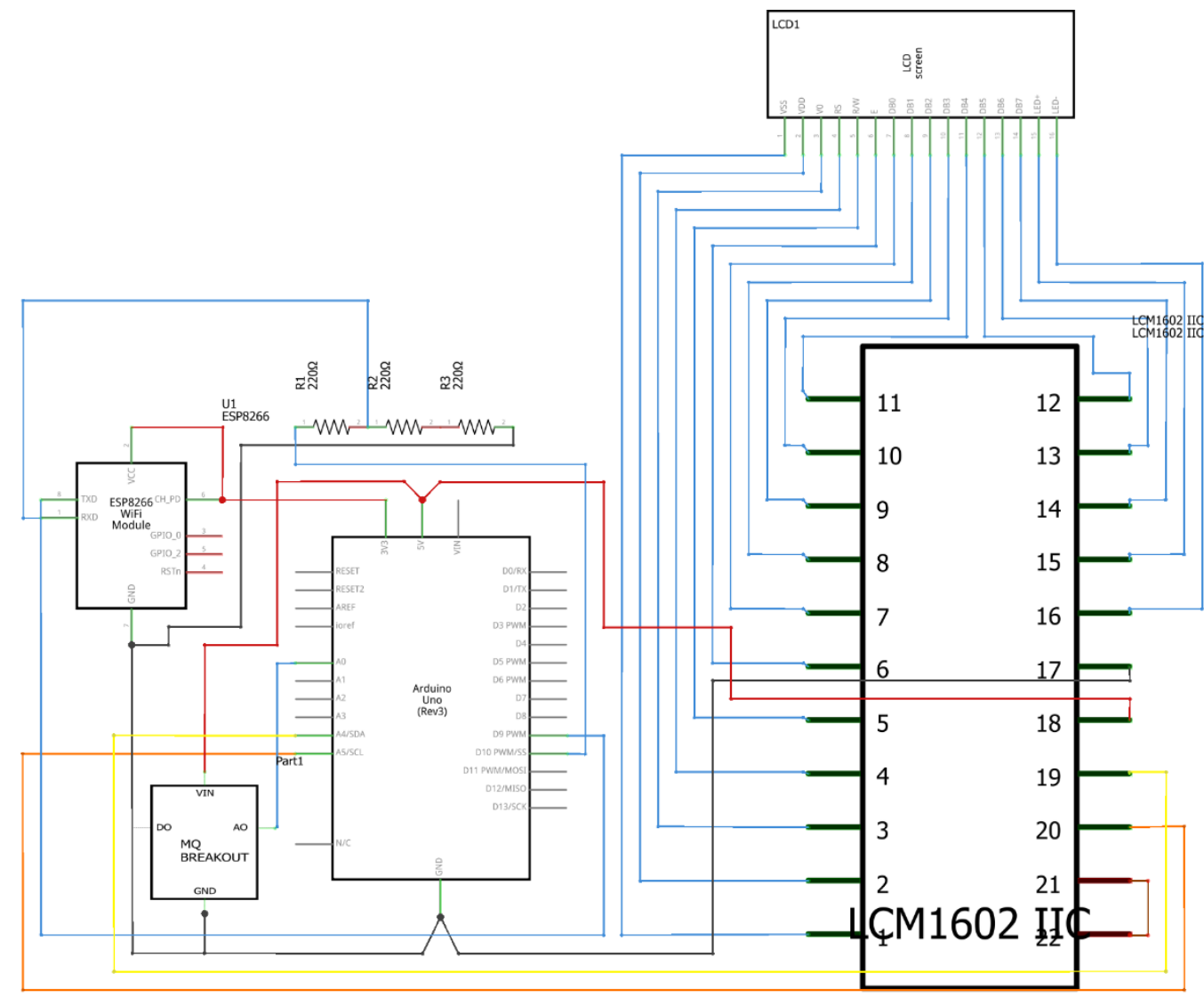

Gambar 2. Skema rangkaian alat

Adapun untuk perancangan rangkaian modul WiFi ESP8266, pin VCC dan CH_PD dihubungkan ke pin 3,3 V Arduino. Pin RX dari ESP beroperasi pada tegangan 3,3 V sehingga jika dihubungkan langsung ke Arduino tidak bisa berkomunikasi. Untuk itu harus dibuat rangkaian pembagi tegangan untuk mengubah $5 \mathrm{~V}$ menjadi 3,3 V. Hal ini dapat dilakukan dengan cara menghubungkan 3 resistor secara seri, setelah itu pin RX data dihubungkan ke pin 9 arduino melalui resistor dan pin TX ESP dihubungkan ke pin 10 Arduino. 
Perancangan rangkaian LCD I2C berfungsi sebagai penampil hasil pemantauan gas CO. Rangkaian LCD ini menggunakan chip tambahan yaitu chip I2C yang membantu LCD lebih efisien dalam penggunaan pin. Tambahan chip I2C ini LCD bisa diakses dengan hanya menggunakan 4 pin yang merupakan pin chip I2C, sehingga dapat memudahkan pengguna untuk merangkai dan mengakses LCD ini. Baterai 9 VDC digunakan untuk mencatu daya keseluruhan komponen. Rangkaian keseluruhan komponen pada alat ini dapat dilihat pada Gambar 2.

\subsection{Perancangan Perangkat Lunak}

Perancangan perangkat lunak ini dilakukan untuk memudahkan dan mendukung kerja sistem pada pengoperasian alat. Perangkat lunak pada alat ini menggunakan software Arduino IDE dan langkah pembuatan rancangan program dapat dilihat pada Gambar 3.

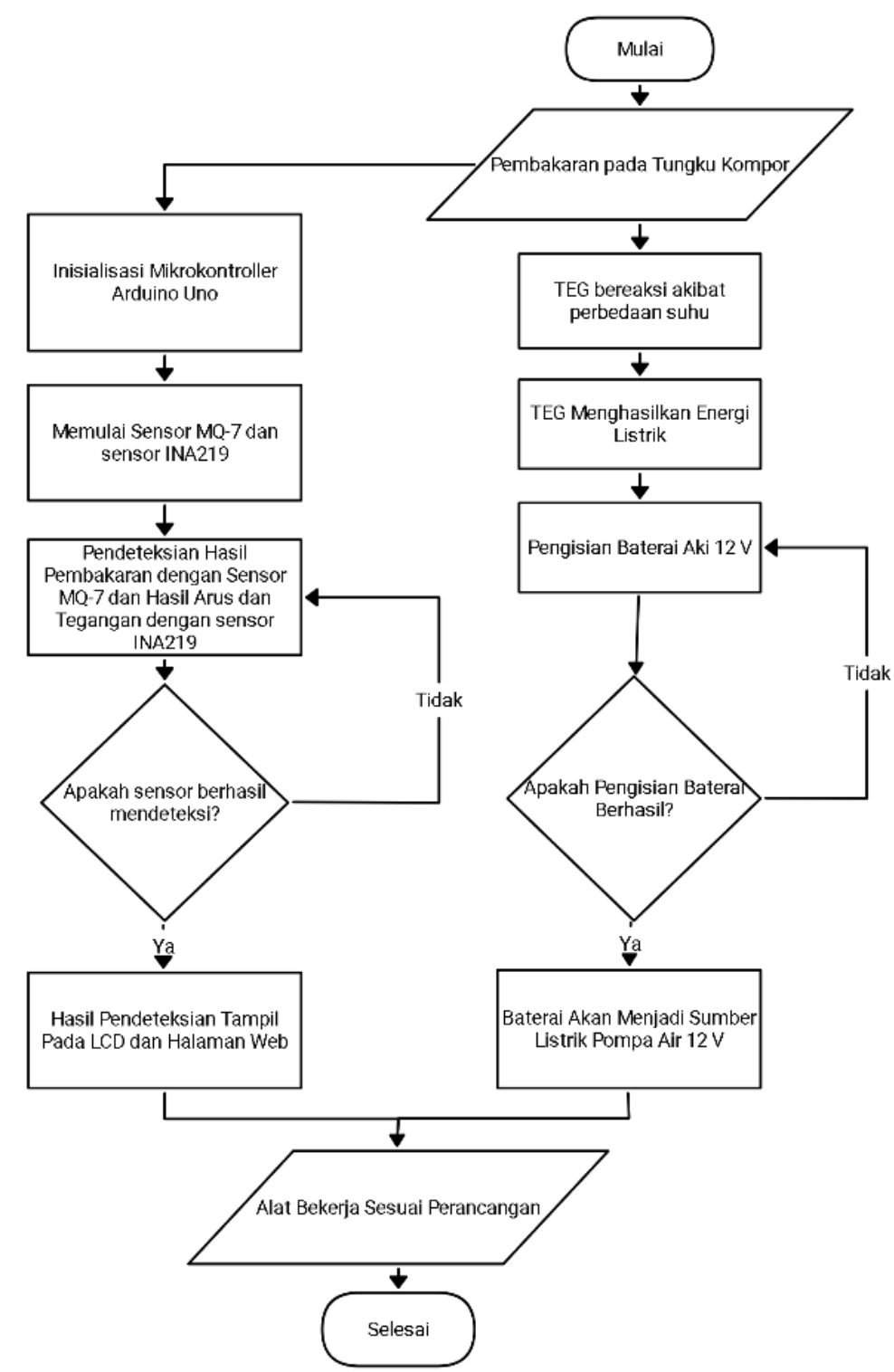

Gambar 3. Flowchart alur kerja sistem 
Diagram di atas merupakan diagram alir dari prinsip kerja sistem pemantauan gas $\mathrm{CO}$ yang dimulai dari inisialisasi Arduino dan dilanjutkan dengan deteksi gas CO hasil pembakaran kompor oleh sensor MQ-7. Pada fungsi kondisi sensor mendeteksi gas CO, maka Arduino mengolah data dan selanjutnya akan menampilkan pada layar LCD dan halaman web. Sebaliknya jika gas CO tidak terdeteksi, maka sensor akan terus bekerja untuk mendeteksi gas $\mathrm{CO}$ yang dihasilkan dari proses pembakaran.

Cara kerja pengiriman data hasil pemantauan ke halaman web dimulai dari membuka web browser lalu memasukkan IP address yang didapat pada serial monitor. Ketika IP address dimasukkan, maka ESP8266 yang berperan sebagai server akan mengirim data hasil pemantauan kadar gas CO dan mencetaknya pada halaman web.

\section{Hasil dan Pembahasan}

\subsection{Kalibrasi sensor MQ-7}

Sensor gas yang digunakan yaitu sensor gas MQ-7 yang befungsi sebagai pengukur konsentrasi gas CO pada produk KOLISS-IoT. Spesifikasi sensor MQ-7 yang digunakan yaitu memiliki sensitivitas tinggi dan respon waktu yang cepat terhadap gas CO [13]. Prinsip kerja sensor MQ-7 menggunakan prinsip resistif yaitu menggunakan perubahan hambatan untuk menentukan nilai konsentrasi gas $\mathrm{CO}$ yang ada di udara. Sensor buatan Hanwei Cina ini terdiri dari keramik $\mathrm{Al}_{2} \mathrm{O}_{3}$, lapisan tipis $\mathrm{SnO}_{2}$, elektroda serta heater yang digabungkan dalam suatu lapisan kerak yang terbuat dari plastik dan stainless. Sensor ini dapat beroperasi ada suhu dari $-10^{\circ} \mathrm{C}$ sampai $50^{\circ} \mathrm{C}$ dan mengkonsumsi kurang dari $150 \mathrm{~mA}$ pada tegangan $5 \mathrm{~V}$. Rentang deteksi gas mencapai 10 - 1000 ppm gas CO [14].

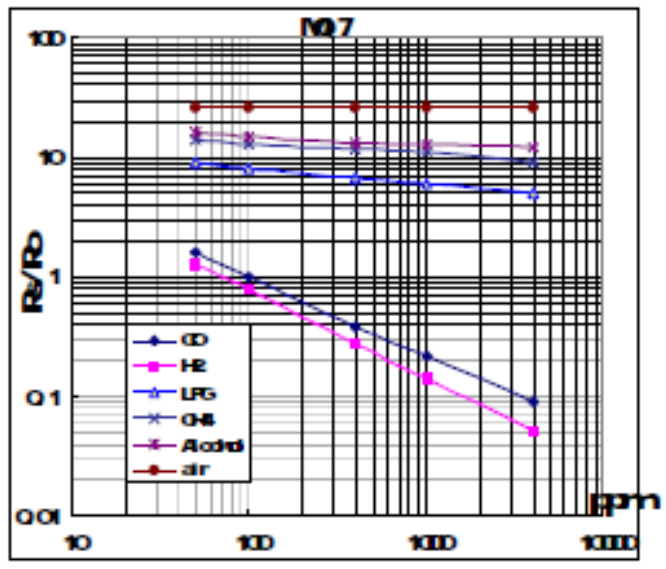

Gambar 4. Grafik karakteristik sensitivitas MQ-7 terhadap gas CO

Gambar 4 menunjukkan karakteristik sensitivitas sensor MQ 7 terhadap gas CO. Dapat dilihat bahwa rasio resistansi sensor $\left(R_{s} / R_{o}\right)$ saat konsentrasi gas $\mathrm{CO} 100 \mathrm{ppm}$ akan bernilai 1 [12]. Nilai konsentrasi gas $\mathrm{CO}$ dalam satuan ppm dapat diketahui dengan cara mengambil beberapa data nilai $R_{s}$ dan kemudian dicari model matematisnya dengan persamaan garis terhadap setiap perubahan gas $\mathrm{CO}$ [15]. Nilai pembacaan $R_{s}$ yang dibaca oleh mikrokontroler dalam bentuk ADC kemudian diolah untuk mendapatkan nilai dari $V_{\text {out }}, R_{s}, R_{s} / R_{o}$. Untuk mencari $V_{\text {out }}$ dan $R_{s}$ digunakan persamaan: 


$$
\begin{gathered}
\text { Vout }=A D C \times V_{c c} / \max A D C \\
R_{s} / R_{L}=\left(\left(V_{c c}-V_{\text {out }}\right) / V_{\text {out }}\right) \\
R_{s}=\left(\left(V_{c c}-V_{\text {out }}\right) / V_{\text {out }}\right) \times R_{L}
\end{gathered}
$$

Keterangan :

$V_{\text {out }} \quad$ : Tegangan keluaran sensor (volt)

$V_{c c} \quad$ : Catu tegangan sensor (volt)

$A D C \quad$ : Analog to Digital Converter

$R_{s} \quad$ : Resistansi sensor pada konsentrasi gas yang berbeda $(\mathrm{k} \Omega)$

$R_{L} \quad$ : Resistansi beban sensor $(\mathrm{k} \Omega)$

Tabel 1. Hasil Pengujian ADC Sensor MQ 7 dengan Kalibrator (ppm)

\begin{tabular}{|c|c|c|c|c|c|}
\hline No. & $\begin{array}{c}\text { Konsentrasi } \\
(\mathrm{ppm})\end{array}$ & $\begin{array}{c}\text { Rata-rata } \\
\mathrm{ADC}\end{array}$ & $\begin{array}{c}\text { Vout } \\
(\text { Volt })\end{array}$ & $\begin{array}{c}R_{s} \\
(\mathrm{k} \Omega)\end{array}$ & $R_{s} / R_{o}$ \\
\hline 1 & 20 & 337,2 & 1,65 & 20,30 & 2,95 \\
\hline 2 & 30 & 369,6 & 1,81 & 17,62 & 2,56 \\
\hline 3 & 40 & 416,6 & 2,04 & 14,51 & 2,11 \\
\hline 4 & 50 & 467 & 2,28 & 11,93 & 1,73 \\
\hline 5 & 60 & 494,8 & 2,42 & 10,66 & 1,55 \\
\hline 6 & 70 & 525,4 & 2,57 & 9,46 & 1,37 \\
\hline 7 & 80 & 564,6 & 2,76 & 8,12 & 1,18 \\
\hline 8 & 90 & 577,4 & 2,82 & 7,73 & 1,12 \\
\hline 9 & 100 & 606,6 & 2,96 & 6,89 & 1 \\
\hline 10 & 110 & 619 & 3,03 & 6,50 & 0,94 \\
\hline 11 & 120 & 639,2 & 3,12 & 6,03 & 0,88 \\
\hline 12 & 130 & 663,4 & 3,24 & 5,43 & 0,79 \\
\hline 13 & 140 & 676,2 & 3,30 & 5,15 & 0,75 \\
\hline 14 & 150 & 591,8 & 3,38 & 4,79 & 0,7 \\
\hline 15 & 160 & 699,2 & 3,42 & 4,62 & 0,67 \\
\hline 16 & 170 & 717,8 & 3,51 & 4,25 & 0,62 \\
\hline 17 & 180 & 730 & 3,57 & 4,01 & 0,58 \\
\hline 18 & 190 & 743,6 & 3,63 & 3,77 & 0,55 \\
\hline 19 & 200 & 760,6 & 3,72 & 3,44 & 0,5 \\
\hline
\end{tabular}

Berdasarkan Tabel 1 dapat dilihat bahwa nilai $R_{s}$ pada saat konsentrasi gas CO 100 ppm adalah sebesar 6,89 $\mathrm{k} \Omega$, yang kemudian akan digunakan untuk proses pengkalibrasian. Karena rasio $R_{s} / R_{o}$ adalah 1 saat 100 ppm, maka dapat disimpulkan bahwa nilai $R_{o}$ besarnya sama yaitu $6,89 \mathrm{k} \Omega$. Selanjutnya dicari model matematis persamaan garis dari hubungan antara ppm $\mathrm{CO}$ dan $R_{s} / R_{o}$ dengan bantuan perangkat lunak Microsoft Excel. 


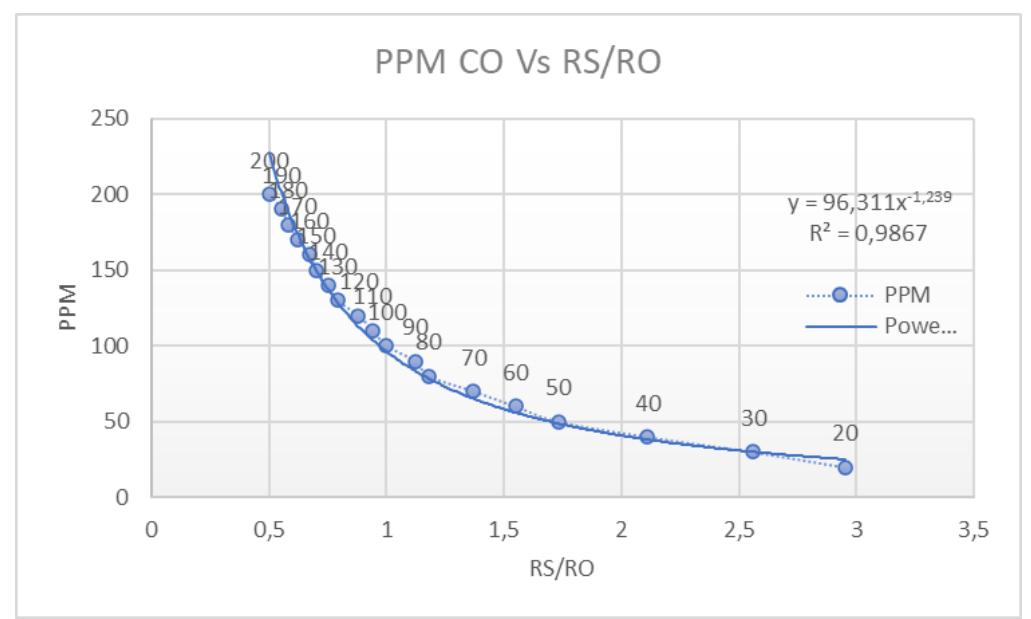

Gambar 5. Grafik ppm gas CO terhadap $R_{s} / R_{o}$

Gambar 5 menunjukkan hubungan antara nilai ppm pada CO Meter dengan nilai resistansi sensor MQ-7 yang ditunjukan pada Tabel 1. Dengan menggunakan regresi trendline power, maka diperoleh persamaan $y=96,311 x^{-1.239}$ yang nantinya digunakan untuk pemrograman Arduino, di mana $y$ adalah konsenttasi gas $\mathrm{CO}$ dan $x$ adalah nilai $R_{s} / R_{o}$.

\subsection{Pengujian Sensor MQ-7}

Pengujian sistem pemantauan gas CO bertujuan untuk menguji apakah sensor MQ-7 dapat mendeteksi gas CO pada tungku pembakaran. Pengujian sensor MQ-7 ini dilakukan sebanyak 3 kali di mana setiap pengujian dilakukan 100 kali pengambilan data dengan rentang waktu 5 detik sehingga didapat 300 data untuk mengetahui kadar gas $\mathrm{CO}$ yang terdapat pada produk KOLISS-IoT ini.

Gambar 6 merupakan hasil pengujian 1 di mana gas CO yang terdeteksi dari hasil pembakaran pada kompor relatif masih rendah dengan rata-rata pendeteksian gas $\mathrm{CO}$ sebesar 4,54 ppm. Standar deviasi dari pengujian 1 sebesar 0,83 yang berarti sebagian besar angka mendekati rata-rata.

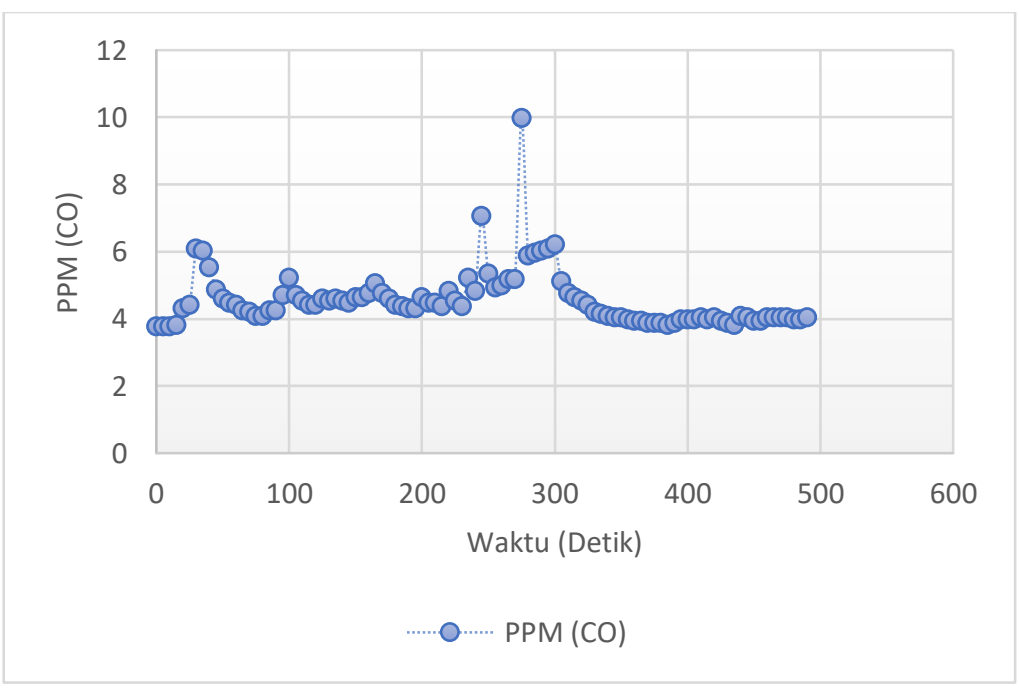

Gambar 6. Grafik nilai konsentrasi gas CO pengujian 1 
Gambar 7 merupakan hasil pengujian 2 di mana gas CO yang terdeteksi dari hasil pembakaran pada kompor relatif masih rendah dengan rata-rata pendeteksian gas $\mathrm{CO}$ sebesar 5,54 ppm. Standar deviasi dari pengujian 2 sebesar 1,01 yang berarti sebagian besar angka mendekati rata-rata.

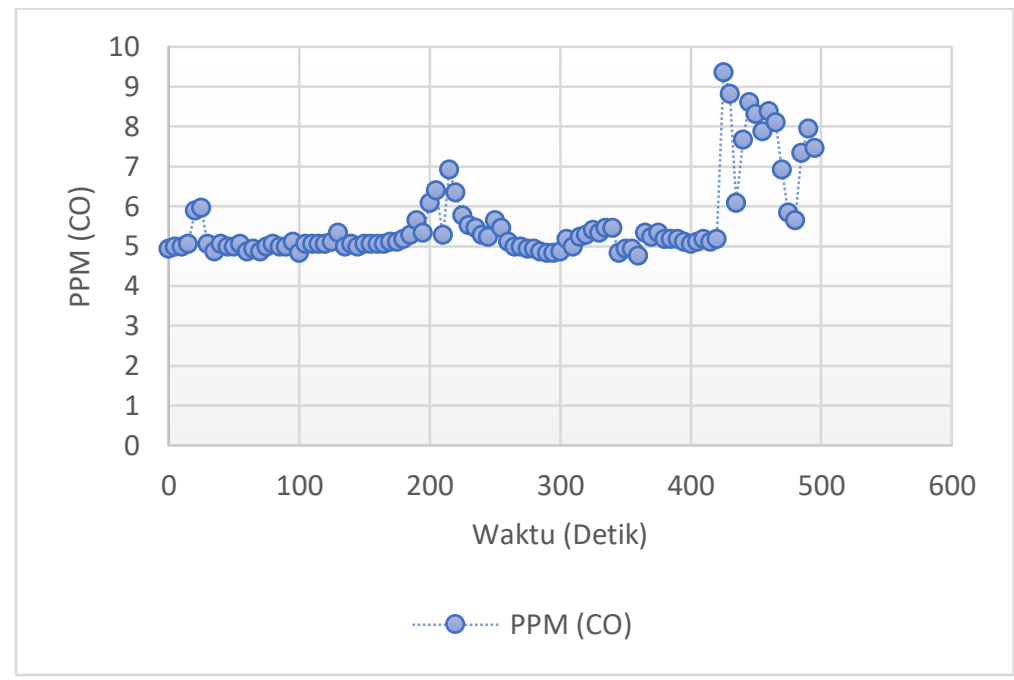

Gambar 7. Grafik nilai konsentrasi gas CO pengujian 2

Gambar 8 merupakan hasil pengujian 3 di mana gas $\mathrm{CO}$ yang terdeteksi dari hasil pembakaran pada kompor relatif masih rendah dengan rata-rata pendeteksian gas $\mathrm{CO}$ sebesar 7,08 ppm. Dapat dilihat pada Gambar 8 juga pada detik ke-460 gas CO yang terdeteksi sangat tinggi yaitu sebesar $211,03 \mathrm{ppm}$. Kenaikan itu disebabkan pada saat pembakaran bahan yang dimasukkan yaitu daun mangga kering yang sudah lapuk. Standar deviasi dari pengujian 3 sebesar 20,60 yang merupakan persebaran datanya besar terhadap nilai rata-rata.

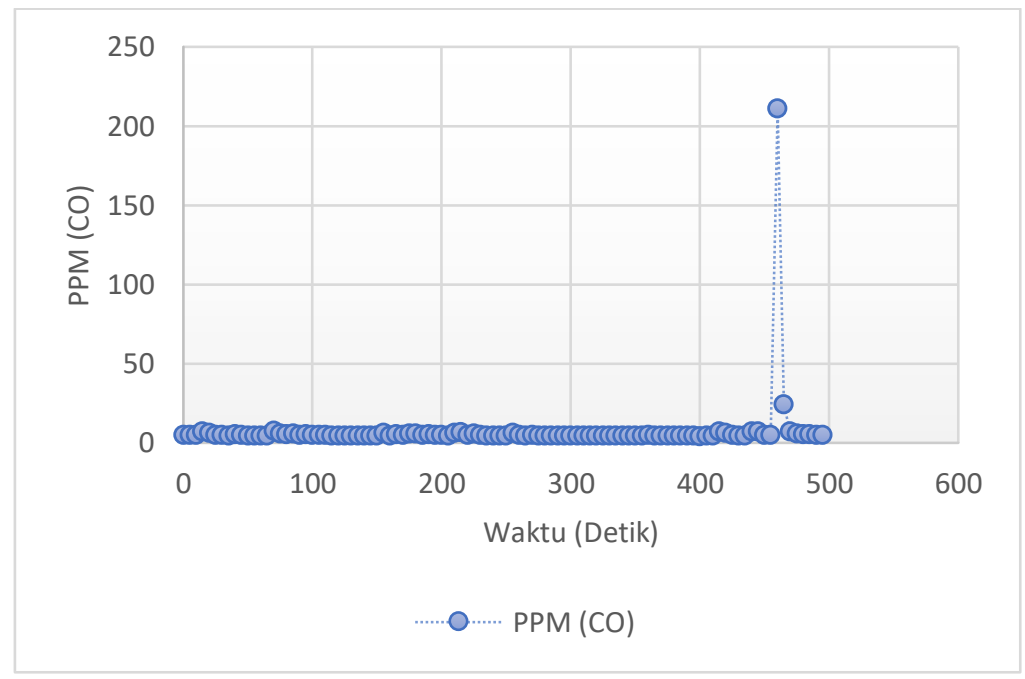

Gambar 8. Grafik nilai konsentrasi gas CO pengujian 3 
Setelah dilakukan 3 kali pengujian diperoleh rata-rata gas $\mathrm{CO}$ yang terdeteksi sebesar $5,72 \mathrm{ppm}$.

\subsection{Pengujian pengiriman data berdasarkan waktu pada halaman web}

Pengujian pengiriman data berdasarkan waktu pada halaman web dilakukan sebanyak 3 kali di mana setiap pengujian dilakukan 10 kali pengambilan data, sehingga didapat 30 data untuk mengetahui seberapa cepat teknologi IoT ini dapat menampilkan hasil pemantauan pada halaman web. Pengujian pengiriman data menggunaan bantuan stopwatch pada ponsel untuk mengukur parameter waktu pengiriman data ke halaman web mulai dari saat IP address dimasukkan pada web browser sampai hasil pemantauan tampil pada halaman web.

Tabel 2 merupakan hasil 3 kali pengujian pengiriman data. Pengujian 1 setelah dilakukan 10 kali pengiriman data, semuanya berhasil dikirim ke halaman web dengan rata-rata waktu pengiriman data sebesar 7,6 detik. Pengujian 2 setelah dilakukan 10 kali pengiriman data dan semuanya berhasil dikirim ke halaman web dengan rata-rata waktu pengiriman data sebesar 7,8 detik. Selanjutnya pada pengujian 3 setelah dilakukan 10 kali pengiriman data semuanya berhasil dikirim ke halaman web dengan rata-rata waktu pengiriman data sebesar 9 detik. Setelah dilakukan 3 kali pengujian diperoleh rata-rata waktu pengiriman data sebesar 8,1 detik.

Tabel 2. Pengujian pengiriman data berdasarkan waktu pada halaman web

\begin{tabular}{|c|c|c|c|c|c|c|}
\hline \multirow{2}{*}{$\begin{array}{c}\text { Pengambilan } \\
\text { Data }\end{array}$} & \multicolumn{2}{|c|}{ Pengujian ke 1} & \multicolumn{2}{|c|}{ Pengujian ke 2} & \multicolumn{2}{|c|}{ Pengujian ke 3} \\
\hline & $\begin{array}{c}\text { Pengiriman } \\
\text { Data }\end{array}$ & $\begin{array}{l}\text { Waktu } \\
\text { (detik) }\end{array}$ & $\begin{array}{c}\text { Pengiriman } \\
\text { Data }\end{array}$ & $\begin{array}{l}\text { Waktu } \\
\text { (detik) }\end{array}$ & $\begin{array}{c}\text { Pengiriman } \\
\text { Data }\end{array}$ & $\begin{array}{l}\text { Waktu } \\
\text { (detik) }\end{array}$ \\
\hline 1 & Berhasil & 4 & Berhasil & 7 & Berhasil & 7 \\
\hline 2 & Berhasil & 5 & Berhasil & 3 & Berhasil & 8 \\
\hline 3 & Berhasil & 5 & Berhasil & 9 & Berhasil & 9 \\
\hline 4 & Berhasil & 8 & Berhasil & 9 & Berhasil & 6 \\
\hline 5 & Berhasil & 7 & Berhasil & 8 & Berhasil & 10 \\
\hline 6 & Berhasil & 8 & Berhasil & 7 & Berhasil & 7 \\
\hline 7 & Berhasil & 10 & Berhasil & 9 & Berhasil & 12 \\
\hline 8 & Berhasil & 6 & Berhasil & 11 & Berhasil & 9 \\
\hline 9 & Berhasil & 9 & Berhasil & 8 & Berhasil & 14 \\
\hline 10 & Berhasil & 11 & Berhasil & 7 & Berhasil & 8 \\
\hline & \multicolumn{2}{|c|}{$\begin{array}{l}\text { Rata-rata waktu } \\
\text { pengiriman data } \\
=7,6 \text { detik }\end{array}$} & \multicolumn{2}{|c|}{$\begin{array}{c}\text { Rata-rata waktu } \\
\text { pengiriman data = } \\
7,8 \text { detik }\end{array}$} & \multicolumn{2}{|c|}{$\begin{array}{c}\text { Rata-rata waktu } \\
\text { pengiriman data }=9 \\
\text { detik }\end{array}$} \\
\hline & \multicolumn{6}{|c|}{ Rata-rata waktu pengiriman data $=8,1$ detik } \\
\hline
\end{tabular}

Tabel 2 memperlihatkan bahwa untuk dapat melihat hasil pemantauan gas $\mathrm{CO}$ pada halaman web dibuituhkan waktu pengiriman data dengan rata-rata 8,1 detik.

Gambar 9 merupakan hasil pengiriman data gas CO yang terdeteksi dan berhasil dikirim serta ditampilkan pada halaman web. Ketika ingin melihat hasil pemantauan selanjutnya pada halaman web, maka dapat dilakukan refresh kembali agar server dapat kembali menampilkannya pada halaman web. 


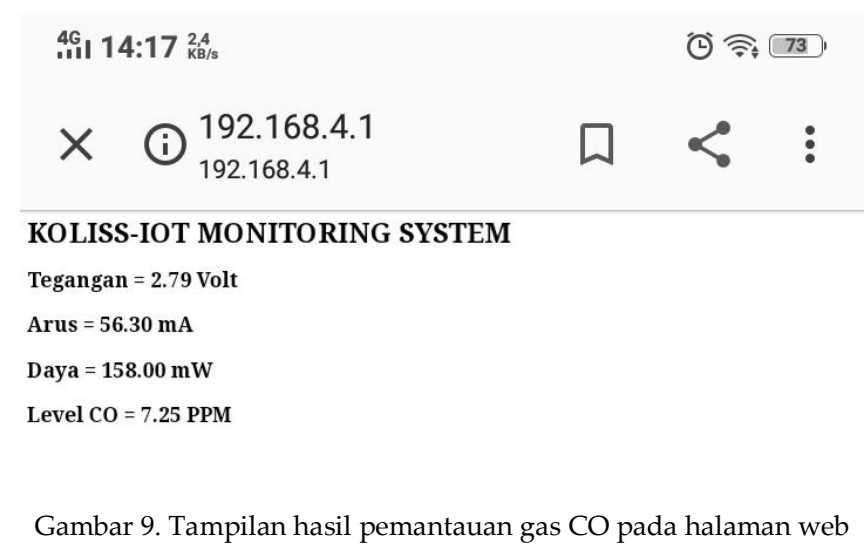

Pengiriman data gas $\mathrm{CO}$ pada halaman web bertujuan untuk memudahkan pengguna dalam memantau gas $\mathrm{CO}$ yang berpotensi dihasilkan dari pembakaran produk, pengguna dapat mengakses hasil pemantauan gas CO kapanpun dan di manapun.

\section{Kesimpulan}

Berdasarkan hasil pengujian pada sistem pemantau gas CO pada produk KOLISS-IoT dapat ditarik kesimpulan bahwa pengujian sensor MQ-7 dapat mendeteksi gas CO dari hasil pembakaran dengan rata-rata pendeteksian gas $\mathrm{CO}$ sebesar 5,72 ppm. Pengujian pengiriman data berdasarkan waktu telah berhasil dilakukan dengan menampilkan hasil pemantauan gas $\mathrm{CO}$ pada halaman web dengan rata-rata waktu pengiriman data sebesar 8,1 detik. Penelitian selanjutnya diharapkan adanya pengembangan pada beberapa bagian seperti pengembangan pada desain cerobong asap supaya gas $\mathrm{CO}$ yang berpotensi dihasilkan dari hasil pembakaran produk dapat terdeteksi secara maksimal dan pengembangan pada teknologi web supaya dapat diakses secara lebih cepat dan realtime.

\section{Daftar Pustaka}

[1] N. Putra, R. A. Koestoer, M. Adhitya, A. Roekettino, and B. Trianto, "Potensi pembangkit daya termoelektrik untuk kendaraan hibrid," MAKARA Journal of Technology Series, vol. 13, no. 2, pp. 53-58, 2009.

[2] A. Haryanto and S. Triyono, "Study for emission characteristic of household stoves," Agritech, vol. 32, no. 4, pp. 425-431, 2012.

[3] N. MacCarty, D. Ogle, D. Still, T. Bond, and C. Roden, "A laboratory comparison of the global warming impact of five major types of biomass cooking stoves," Energy Sustain. Dev., vol. 12, no. 2, pp. 56-65, 2008, doi: 10.1016/S0973-0826(08)60429-9.

[4] E. Duflo, M. Greenstone, R. Hanna, and G. Vikas, "Cooking stoves, indoor air pollution, and respiratory health in India, AEA RCT Registry, October 2016.

[5] T. Akhtar, Z. Ullah, M. H. Khan, and R. Nazli, "Chronic bronchitis in women using solid biomass fuel in rural Peshawar, Pakistan," Chest, vol. 132, no. 5, pp. 1472-1475, 2007, doi: 10.1378/chest.06-2529.

[6] V. Mishra, "Effect of indoor air pollution from biomass combustion on prevalence of asthma in the elderly.," Environ. Health Perspect., vol. 111, no. 1, pp. 71-78, 2003, doi: 10.1289/ehp.5559.

[7] D. G. Fullerton, N. Bruce, and S. B. Gordon, “Indoor air pollution from biomass fuel 
smoke is a major health concern in the developing world," Trans. R. Soc. Trop. Med. Hyg., vol. 102, no. 9, pp. 843-851, 2008, doi: 10.1016/j.trstmh.2008.05.028.

[8] Y. Fikri, S. Sumardi, and B. Setiyono, "Sistem monitoring kualitas udara berbasis mikrokontroler Atmega 8535 dengan komunikasi protokol TCP/IP," Transient, vol. 2, no. 3, pp. 643-650, 2013.

[9] L. O. Sari, E. Safrianti, and R. Sirait, "Analisa respon dan sensitifitas alat deteksi kadar polutan karbon monoksida (CO) di udara dengan sensor TGS 26," Arsitron, vol. 5, no. 1, p. 53, 2014.

[10] https://www.engineeringtoolbox.com/carbon-monoxide-d_893.html, diakses tanggal 3 Mei 2020.

[11] A. Junaidi, "Internet of Things, Sejarah, Teknologi Dan Penerapannya : Review," J. Ilm. Teknol. Inf. Terap., vol. 1, no. 3, pp. 62-66, 2015.

[12] M. A. A. Prakoso and L. Rakhmawati, "Sistem monitoring kadar karbon monoksida (CO) pada cerobong asap industri dengan komunikasi bluetooth melalui smartphone Android" J. Tek. Elektro, vol. 07, no. 01, pp. 23-30, 2018.

[13] S. H. Maharani, N. Kholis, "Studi literatur: Pengaruh penggunaan sensor gas terhadap persentase nilai error karbonmonoksida (CO) dan hidrokarbon (HC) pada prototipe vehivel gas detector (VGD) " J. Tek. Elektro, vol. 09, no. 03, pp. 569-578, 2020.

[14] I. W. A. Wibawa, I. G. Bagus, W. Kusuma, and I. M. Widiyarta, "Perancangan alat uji detektor emisi gas buang yang dilengkapi dengan interface komunikasi USB," Logic : Jurnal Rancang Bangun dan Teknologi, vol. 15, no. 2, pp. 69-75, 2015.

[15] R. Apriliansyah Dwi Saputra, "Prototipe Pengendali Kualitas Udara Indoor Berbasis Mikrokontroler Atmega 328P," Skripsi D3 Teknik Elektronika UNY, 2017. 